\title{
Meaning and Functions of State Administrative Assets Reports in a Clean and Free Country Management of Colusion, Corruption and Nepotism
}

\author{
Nur Chusniah; Sudarsono; I Nyoman Nurjaya; Abdul Madjid \\ Faculty of Law, Universitas Brawijaya, Indonesia \\ http://dx.doi.org/10.18415/ijmmu.v8i12.3278
}

\begin{abstract}
The type of research used in this research is normative legal research. Considering the RASA as the prevention and prosecution of criminal acts of corruption, collusion and nepotism, where this task is entrusted to the Corruption Eradication Commission, it encourages the Government and the House of Representatives to give authority to the CEC as an institution that imposes sanctions on state administrators in relation to non-compliance with the obligation to report RASA in the amendments to the Law. Law No. 28/1999 concerning the Implementation of a Clean and Corruption-Free State, Collusion and Nepotism or the Law on the Corruption Eradication Commission, which so far have been sanctioned for non-compliance with the obligation to report RASA to the respective agencies where the State Administrator is located. In this regard, the author proposes that the CEC be given the authority to impose sanctions on Providers who do not comply with reporting RASA and also those who are dishonest in reporting RASA, so that the meaning of the RASA function is not only preventive in nature but also action is realized as well as for State Organizers not to play games in carrying out their obligations to report RASA.
\end{abstract}

Keywords: Assets; Management; Law

\section{Introduction}

The development of corruption to date is the result of an uneven government administration system in an orderly manner and not properly supervised because the legal basis used contains many weaknesses so that in its application by law enforcers there are also obstacles in realizing justice and legal certainty. Supported by a weak "Check and Balances" system, corruption has become institutionalized and is approaching a culture that is almost difficult to eradicate.(Atmasasmita, n.d.)

In preventing corruption, it is known as the Report on Assets of State Administrators (RASA), which is a mechanism for reporting assets that is required for every State Administrator as regulated in Article 5 of the Law of the Republic of Indonesia Number 28 of 1999 concerning the Implementation of a Clean and Corruption-Free State, Collusion and Nepotism (Law No. 28 of 1999) specifically the obligation in point 2 which formulates that State Administrators are obliged to "be willing to have their wealth checked before, during and after taking office" and point 3 formulates that "report and announce their wealth before and after taking office." 
The ontology of reporting obligations is honesty (honesty value) to report assets owned before, during and after serving as a State Administrator as the embodiment of the norm in Article 5 Paragraph (3) of Law no. 28 of 1999, that "Every State Administrator is obliged to report, and announce wealth before, and after taking office". Furthermore, regarding the examination of State Administrators' Wealth, it is regulated separately in Article 5 Paragraph (2) of Law No. 28 of 1999, that "Every State Administrator is obliged to be willing to have his wealth checked before, during, and after taking office. These two articles became the forerunner to the emergence of the RASA concept. Being an interesting legal issue, in Law 28 of 1999 there is not a single article that uses the term RASA but only the obligation to report and announce wealth in Article 5 in conjunction with Article 20 in Law 28 of 1999 concerning State Administration that is clean and free from corruption, collusion and Nepotism. The term RASA first appeared in Article 13 of Law No. 30 of 2002 which in point (a) states that the Corruption Eradication Commission (CEC) has the authority to carry out preventive measures or efforts by "registering and examining the wealth reports of state officials".

Epistemologically the existence of RASA is to find out the assets owned by State Administrators before, during, and after taking office. Through the RASA method, it can be known whether the State Administrator has integrity that is in line with the principles of good governance in relation to the administration of the State and in relation to evidence in court of corruption. With the RASA reporting method using Self Assessment, is it able to guarantee the honesty of State Administrators in reporting their assets, even though what actually happens is that there is an opportunity for dishonesty in filling out the RASA itself.

In the axiological approach, the estuary and substance in Law no. 28 of 1999 is a preventive effort for State Administrators in implementing good governance and free from corruption. A person's personal integrity in his capacity as a State Administrator is important to maintain the authority of the State Administrator, no matter how good the laws and regulations are, if an official doesn't have a personal integrity, he will always take advantage of opportunities or loopholes in the laws and regulations or even look for weaknesses in the regulations the legislation.

As the purpose of the enactment of Law No. 28 of 1999 concerning State Organizers that are Clean and Free from Corruption, Collusion and Nepotism so that the realization of a State that is clean and free from Corruption, Collusion and Nepotism (CCN) based on the general principles of good governance then one way is to require State Administrators to announce and report assets before, during and after serving (RASA) to the CEC (vide Article 13 of Law No.30 of 2002 concerning the Corruption Eradication Commission). However, in reality the obedience/compliance of State officials in reporting RASA to the CEC has not had a significant impact on corruption issues in Indonesia. Based on the description above, there is an interesting legal issue to conduct a research with the formulation of what is the function and meaning of the RASA for State Administrators in the administration of the State that is free from $\mathrm{CCN}$.

\section{Research Methods}

The type of research used in this research is normative legal research.(Soerjono Soekanto, 2012)

\section{Discussion}

The important substance and meaning of RASA contains noble values which can be explained as follows:(Tim SPORA, 2015).

a. Transparency or openness is the key word to build civilization. This adage seems fitting to describe what if the State Administrators have the desire to participate in supporting anti-corruption 
activities by consciously reporting the RASA to the CEC and updating it regularly. This will be a big capital for a clean and accountable government.

b. Accountability. When the government is clean, the responsibility of the State Organizers to best serve the people can be fulfilled. When the trust capital has emerged to the State Administrators, the public will also automatically be responsible for their obligations to the state. Whether it's paying taxes, or other obligations attached to being a citizen.

c. Participation. Community participation is also high in supervising State Administrators. For example, when they find assets that are underpriced, they can report to the CEC that the land or building reported by the State Administrator is not true. Likewise for reporters, with transparency like this they shouldn't play around in reporting. Must be validated by a competent appraiser on land, building, or other immovable assets.

According to the explanation in Article 3 point 7 of Law No. 28 of 1999, the principle of accountability is defined as the principle that determines that every activity and the final result of the activities of a State Organizer must be accountable to the community or the people as the holder of the highest sovereignty of the state in accordance with the provisions of the applicable laws and regulations. The obligation to report assets for State Administrators and candidates for State Organizers within the framework of good governance and efforts to eradicate corruption is principally the embodiment of the principle of noblesse oblige, which means that honor carries obligations and responsibilities. As mentioned in the study of theeffectiveness of the mechanism for reporting the wealth of State Administrators for eradicating corruption in Indonesia, the Corruption Eradication Commission makes an inventory of various objectives to be achieved in terms of reporting assets. The objectives of the report include:

First, to test the integrity of the candidates for state administrators, reporting on the wealth of state officials can be seen as a transparency effort that will bring public confidence in the integrity of state administrators. For this purpose, of course, the report must be published in such a way that public access to information on the wealth of state officials is not restricted.

Second, it creates fear among state officials to commit corruption. With the obligation to report wealth regularly, every state administrator will feel monitored both by the public and by the authorized institution from time to time.

Third, instilling honesty, openness, and responsibility (ethical character) among State Administrators. By internalizing the nature of honesty, openness, and responsibility through the obligation to report wealth as a form of ethical behavior of state administrators, it is hoped that this will gradually have implications for the integrity, transparency, and accountability of the state administration system as a whole.

Fourth, detect (potential) conflicts of interest between the public duties of state administrators and their personal interests. Especially for (elected officials), the potential for conflict between public interests in office and individual interests influenced by the background of the officials concerned is very large.

Fifth, provide preliminary evidence and/or supporting evidence for the investigation and prosecution of corruption cases. Wealth reports as initial evidence of corruption investigations have the potential to be applied after the enactment of Law no.20 of 2001, in particular Article 12B regarding gratification. Grants to state officials that are contrary to their obligations are expected to be traced through their wealth reports. 
Sixth, increasing public control over state administrators. This objective is indirectly represented by the obligation of state officials to report their wealth. By making the wealth report of state administrators public domain through an announcement mechanism, the public can access the report, and make it a means of controlling state administrators, especially regarding indications of irregularities in their wealth.

The existence of administrative sanctions in Law Number 28 of 1999 Article 20 paragraph (1) for State Administrators who do not report their assets only use the norm of obligations without being balanced by the norms of authority of the implementing agency.(Sihombing, 2012) Obligations and sanctions regarding RASA in Law No. 28/1999, at first glance, do not show any problems. However, the norms in the law are not clear. The indecision is stated in Article 5 of Law Number 28 of 1999 which only uses the norms of the obligations of the State Administrators without being balanced with the norms of the authority of the implementing institutions. Law No. 28/1999 doesn't explain the institution that has the authority to examine and ensure that RASA is reported and published, as well as to impose sanctions on the said State Administrators.

Regarding the article on sanctions above, those who violate the obligation to report their assets are charged to their respective agencies, namely the agency that oversees the State Organizer, whereas the CEC has the authority to register and examine RASA. So far, in practice, the CEC cooperates with the inspectorate or supervisory body in each institution/agencies to provide reports on compliance and noncompliance in reporting RASA. If anyone has not reported then the imposition of sanctions is carried out by the Inspectorate/supervisory agency.

Law Number 30 of 2002 in conjunction with Law 19 of 2019 concerning the CEC, explains the authority of the CEC to register and examine the RASA as one of the efforts to prevent corruption. However, there is no article that authorizes the CEC to participate in enforcing sanctions for State Administrators who violate their obligations to report assets. If someone violates the obligation to report their assets, the CEC can only provide a compliance list containing people who comply and those who do not comply with RASA in an agency to the agency that falls for sanctions.(Harmono, 2020)

Regarding administrative sanctions given to state administrators by imposing them on the leadership of each agency, it is generally regulated by laws and regulations. By looking at this, it can cause the sanctions imposed by each leader to be different for each agency because it is not regulated more specifically by laws and regulations. Not to mention if the Head of the Agency is not firm in giving sanctions to state officials who don't comply with RASA reporting. So that it requires sanctions that are binding on state administrators. Establishment of strong regulations so that the CEC has coercive power against State administrators who are negligent in the RASA report.(Nazhiri, 2019)

\section{Conclusion}

Considering the RASA as the prevention and prosecution of criminal acts of corruption, collusion and nepotism, where this task is entrusted to the Corruption Eradication Commission, it encourages the Government and the House of Representatives to give authority to the CEC as an institution that imposes sanctions on state administrators in relation to non-compliance with the obligation to report RASA in the amendments to the Law. Law No. 28/1999 concerning the Implementation of a Clean and CorruptionFree State, Collusion and Nepotism or the Law on the Corruption Eradication Commission, which so far have been sanctioned for non-compliance with the obligation to report RASA to the respective agencies where the State Administrator is located.

In this regard, the author proposes that the CEC be given the authority to impose sanctions on Providers who do not comply with reporting RASA and also those who are dishonest in reporting RASA, so that the meaning of the RASA function is not only preventive in nature but also action is realized as well as for State Organizers not to play games in carrying out their obligations to report RASA. 


\section{References}

Atmasasmita, R. (n.d.). Sekitar Masalah Korupsi Aspek Nasional dan Aspek International. Mandar Maju.

Harmono, D. (2020). Kewajiban Pelaporan Harta Kekayaan Bagi Penyelenggara Negara. Jurnal Universitas Semarang Law Review.

Nazhiri, A. F. (2019). Implementasi Sanksi Administrasi LHKPN Terhadap Terciptanya Pemerintahan yang Bersih dan Bebas dari KKN. UIN Syarif Hidayatullah Jakarta.

Sihombing, M. M. A. A. S. (2012). Pelaksanaan Pelaporan Harta Kekayaan Penyelenggara Negara Sebagai Upaya Pencegahan Tindak Pidana Korupsi.

Soerjono Soekanto, S. M. (2012). Penelitian Hukum Normatif: Suatu Tinjauan Singkat (R. Press (ed.)).

Tim SPORA, D. P. dan P. M. K. B. P. K. P. K. (2015). Pengantar Laporan Harta Kekayaan Penyelenggara Negara (LHKPN). Komisi Pemberantasan Korupsi.

\section{Copyrights}

Copyright for this article is retained by the author(s), with first publication rights granted to the journal.

This is an open-access article distributed under the terms and conditions of the Creative Commons Attribution license (http://creativecommons.org/licenses/by/4.0/). 